\title{
Pengaruh Instar Larva Inang Spodoptera litura Fabricius (Lepidoptera: Noctuidae) terhadap Keberhasilan Hidup Parasitoid Eriborus argenteopilosus Cameron (Hymenoptera: Ichneumonidae)
}

\author{
NOVRI NELLY*, YUNISMAN DAN YULIA RAHMAWATI
}

Jurusan Hama dan Penyakit Tanaman, Fakultas Pertanian, Universitas Andalas Padang, Kampus Unand Limau Manis, Padang 25163.

(diterima Januari 2011, disetujui Maret 2011)

\begin{abstract}
ABSTRAK
Pengaruh Instar Larva Inang Spodoptera litura Fabricius (Lepidoptera: Notuidae) terhadap Keberhasilan Hidup Parasitoid Eriborus argenteopilosus Cameron (Hymenoptera: Ichneumonidae). Penelitian pengaruh instar larva inang terhadap keberhasilan hidup parasitoid E. argenteopilosus telah dilakukan di laboratorium Departemen Agroteknologi, Fakultas Pertanian, Universitas Andalas. Keberhasilan hidup diteliti dengan menggunakan instar larva S. litura dengan stadia yang berbeda (instar I, II, III, dan IV). Hasil penelitian menunjukkan bahwa laju perkembangan parasitoid $E$. argenteopilosus lebih cepat terjadi pada larva inang instar 3, semakin tinggi tingkatan instar larva inang, semakin pendek waktu untuk menyelesaikan siklus hidupnya. Jumlah pupa yang terbentuk adalah 14 pupa $(4,67 \%)$, dan parasitoid yang berhasil menjadi imago adalah 3 ekor (1\%), imago yang muncul hanya imago jantan.
\end{abstract}

KATA KUNCI: Perkembangan parasitoid, interaksi inang parasitoid, keberhasilan hidup.

\section{ABSTRACT}

Development Stage of The Host Larvae, Spodoptera litura Fabricius (Lepidoptera: Noctuidae) and its Effect on The Survivorship of The Parasitoid Eriborus argenteopilosus Cameron (Hymenoptera: Ichneumonidae). Research on the effect of host larval stage on survivorship of the parasitoid E. argenteopilosus was conducted under laboratory conditions. Survivorship was studied by using $S$. litura larval with different stage $\left(1^{\text {st }}\right.$, $2^{\text {nd }}, 3^{\text {rd }}$, and $4^{\text {th }}$ instars). Result of the research indicated that development rate of the parasitoid E. argenteopilosus is faster when reared on $3^{\text {rd }}$ instar larvae. The higher the level of host-instar larvae, shorter time was needed to complete the parasitoid's life cycle. Only $4.67 \%$ of the larvae completed its development to pupal stage, and only $1 \%$ reached adulthood, with males being the dominant of the emerging adults.

KEY WORDS: Parasitoid development, host parasitoid interaction, survivorship.

\footnotetext{
*Korespondensi:

Telp.: +62-751-72701,

Faks: +62-751-72702, E-mail:novrinelly@yahoo.com
} 


\section{PENDAHULUAN}

Eriborus argenteopilosus Cameron (Hymenoptera: Ichneumonidae) merupakan parasitoid larva pada beberapa serangga hama (Othman 1982).

Parasitoid ini dulu diberi nama Inareolata sp. (Hymenoptera: Ichneumonidae) sekarang parasitoid ini lebih dikenal dengan nama $E$. argenteopilosus Cameron. Serangga hama yang merupakan inang E. argenteopilosus adalah Crocidolomia pavonana Fabricius (Lepidoptera: Pyralidae), Spodoptera litura Fabricius (Lepidoptera: Noctuidae) dan Helicoverpa armigera Fabricius (Lepidoptera: Noctuidae) (Kalshoven 1981).

Banyak faktor yang mempengaruhi kehidupan parasitoid ini, faktor biotik dan abiotik. Keberadaan inang adalah salah satu faktor biotik yang mempengaruhi kehidupan parasitoid. Keberadaan parasitoid di lapangan sangat dipengaruhi oleh keberadaan inang. Dalam siklus hidupnya parasitoid ini memerlukan larva inang untuk perkembangannya. Telur yang diletakkan pada larva inang akan berkembang sesuai dengan perkembangan inangnya. Keadaan curah hujan, kelembaban dan ketersediaan pakan adalah diantara faktor abiotik yang mempengaruhinya (Nelly 2005).

Di Indonesia studi tentang keberhasilan hidup E. argenteopilosus pada berbagai inang belum banyak dilapor- kan. Informasi mengenai keberhasilan hidup parasitoid pada berbagai inang sangat berguna untuk menentukan inang mana yang sesuai bagi perkembangan parasitoid. Beberapa penelitian yang dilakukan pada larva $C$. pavona$n a$ sebagai inang menunjukkan adanya enkapsulasi telur E. argenteopolosus. Enkapsulasi yaitu adanya suatu proses dalam tubuh inang yang mekanismenya dimulai dengan terbentuknya gelembung atau gumpalan darah serangga membentuk suatu rantai yang mengelilingi telur atau larva parasitoid. Parasitoid yang dienkapsulasi akan mati karena kekurangan nafas, kelaparan atau penghambatan secara fisik (Strend \& Pech 1995, Blumberg 1997 dalam Anindhita 2000). Hal ini adalah salah satu yang menyebabkan rendahnya populasi parasitoid E. argenteopilosus di lapangan. Selain C. pavonana, inang lain parasitoid ini adalah $S$. litura. Diharapkan dari S. litura tidak terjadi enkapsulasi sehingga perbanyakan bisa berhasil dengan baik. Sahari (1999) menyatakan bahwa keberhasilan hidup parasitoid $E$. argenteopilosus pada $S$. litura jumlahnya jauh lebih baik dibandingkan dari larva C. pavonana. Belum banyak dilaporkan tentang tingkat keberhasilan hidup E. argenteopilosus pada $S$. litura dengan instar yang berbeda. Untuk itu telah dilakukan penelitian dengan tujuan untuk mengetahui pengaruh tingkatan instar larva inang terhadap keberhasilan hidup parasitoid. 


\section{METODE PENELITIAN}

Penelitian ini dilaksanakan di Laboratorium Entomologi, Jurusan Hama dan Penyakit Tumbuhan, Fakultas Pertanian, Universitas Andalas. Pengambilan sampel parasitoid dan inangnya dilakukan di pertanaman kubis di Aia Angek Kabupaten Tanah Datar Sumatera Barat. Penelitian dilakukan pada bulan Mei sampai Juli 2007

\section{Penyediaan Parasitoid Serangga Inang}

Parasitoid E. argenteopilosus jantan dan betina, diambil dari pertanaman kubis petani di daerah Aia Angek, dengan menangkap imago parasitoid menggunakan jaring serangga (insect net). Parasitoid yang didapat dari lapangan langsung digunakan untuk perlakuan. Parasitoid yang diambil adalah yang berukuran hampir sama untuk menyamakan tingkat kebugarannya.

Larva serangga inang dikoleksi dari pertanaman yang sama dengan tempat pengambilan parasitoid. Larva yang diperoleh dari lapangan dipelihara dalam kotak plastik berukuran 35 $\mathrm{cm} \times 27 \mathrm{~cm} \times 7 \mathrm{~cm}$ yang dialasi kertas tissue, kemudian larva diberi pakan daun kubis sesuai dengan kebutuhan dan pakan larva diganti setiap hari. Larva yang memasuki masa prapupa dikeluarkan dari kotak pemeliharaan larva, kemudian dipindahkan ke kotak plastik yang berukuran $30 \mathrm{~cm}$ x $20 \mathrm{~cm}$ $x 10 \mathrm{~cm}$ dan diberi serbuk gergaji sebagai media untuk membentuk pupa. Imago jantan dan betina yang keluar dipelihara dalam kurungan yang terbuat dari kain kassa berbingkai kayu berukuran $50 \mathrm{~cm} \times 50 \mathrm{~cm} \times 50 \mathrm{~cm}$. Imago diberi pakan dengan larutan madu yang sudah diencerkan dan diserapkan pada segumpal kapas. Untuk tempat peletakkan telur ke dalam kurungan dimasukkan daun kubis yang pangkalnya dicelupkan ke dalam botol film yang berisi air untuk menjaga daun agar tetap segar. Setiap hari telur yang diletakkan imago diambil dan ditempatkan ke dalam petri sampai menetas. Setelah telur menetas, larva dipelihara dalam kotak pemeliharaan dan diberi pakan daun kubis sampai terbentuk masing-masing instar dan siap diperlakukan. Sebagian larva digunakan untuk percobaan dan sebagian lagi untuk perbanyakan.

Imago parasitoid yang diperoleh dari lapangan dibiarkan berkopulasi, yaitu dengan cara mengurung parasitoid selama 12 jam. Masing-masing penyediaan instar larva $S$. litura (instar ke-1, ke-2, ke-3, dan ke-4) diberikan satu persatu pada parasitoid di dalam tabung reaksi sampai benar-benar diletakan telur, larva yang terparasit adalah larva yang telah ditusuk oleh ovipositor parasitoid. Larva yang sudah terparasit sebanyak 30 ekor dipindahkan ke dalam wadah plastik berbentuk mangkok yang berukuran tinggi $7 \mathrm{~cm}$ dan diameter $10 \mathrm{~cm}$. Wadah tersebut terlebih dahulu dialasi dengan kertas 
tissue dan diberi daun kubis sebagai pakan larva. Percobaan ini dilakukan sebanyak 10 kali ulangan untuk masing-masing stadia larva, dengan total masing-masing larva terparasit adalah 300 larva.

Larva yang telah diparasitkan diamati lama perkembangannya sampai terbentuk prapupa parasitoid. Pengamatan dilakukan setiap hari. Lama perkembangan telur-prapupa dihitung mulai dari larva inang diparasitkan sampai terbentuk prapupa. Pengamatan dilakukan hanya dengan mengamati larva terparasit yang dipelihara (tidak dibedah).

Lama stadia pupa dihitung mulai terbentuk prapupa sampai muncul imago. Prapupa parasitoid yang terbentuk diamati perkembangannya setiap hari sampai muncul imago.

Lama perkembangan (development time) dihitung mulai dari larva terparasit sampai muncul imago parasitoid. Pengamatan dilakukan setiap hari. dengan cara Lauziere (2000), untuk mendapatkan laju pertumbuhan yaitu sebagai berikut:

$\mathrm{DR}=1 / \mathrm{DT}$, dengan DR = Laju perkembangaan dan DT = Lama perkembangan.

Jumlah pupa parasitoid dihitung dengan cara menjumlahkan keseluruhan pupa yang terbentuk dari setiap ulangan.

Jumlah imago parasitoid dihitung dengan cara menjumlahkan keseluruh- an imago yang muncul dari setiap ulangan.

\section{HASIL DAN PEMBAHASAN}

\section{Lama Perkembangan Telur -} Prapupa E. argenteopilosus

Hasil pengamatan lama perkembangan telur parasitoid, yaitu mulai dari telur diletakkan sampai terbentuk prapupa, menunjukkan perbedaan yang nyata pada tiap perlakuannya (Tabel $1)$.

Dari tabel di atas dapat dilihat bahwa larva inang instar 1, 2, 3 dan 4 yang diletakai telur oleh parasitoid pada umumnya masih berkembang. Hal ini dapat dilihat dari pupa yang terbentuk, yaitu pada inang instar 1, 2, dan 3. Tidak satupun pupa parasitoid ter-bentuk dari larva inang instar 4, hal ini diduga karena sudah ada pertahanan terhadap parasitoid oleh inang. Perkembangan larva - prapupa paling cepat terjadi pada inang instar 3 yaitu 12,6 $\pm 3,7$ hari, dilanjutkan larva inang instar 2 yaitu 15,60 $\pm 2,1$ hari dan larva inang instar 1 yaitu 19,50 $\pm 2,8$ hari.

\section{Lama Stadia Pupa}

Hasil pengamatan lama stadia pupa yang terbentuk dari larva inang instar 1 dan 2 menunjukkan perbedaan. Pupa yang berasal dari larva inang instar 1 lebih lama perkembangan stadia pupanya dibandingkan dengan pupa yang berasal dari larva inang instar 2. Lama stadia pupa instar 1 adalah 10 
$\pm 3,16$ dan instar 2 adalah $8,5 \pm 3,6$ hari (Tabel 1).

\section{Laju Perkembangan $E$. argenteopilosus}

Hasil pengamatan laju perkembangan pradewasa E. argenteopilosus yaitu dari telur - prapupa yang paling cepat terjadi pada larva inang instar 3 yaitu $0,079 \pm 0,96$ hari $^{-1}$. Sedangkan pada larva inang instar 2 yaitu $0,064 \pm$ 0,011 hari $^{-1}$ dan seterusnya pada larva inang instar 1 yaitu $0,051 \pm 0,009$ hari $^{-1}$.

\section{Jumlah Pupa Parasitoid yang Terbentuk}

Hasil pengamatan jumlah parasitoid yang terbentuk menunjukkan bahwa pupa yang paling banyak terbentuk adalah dari larva inang instar 2 yaitu 10 pupa. Pupa yang terbentuk dari larva inang instar 1 adalah 3 pupa, dan instar 3 sebanyak 1 pupa.

Tabel 1. Rata-rata lama dan laju perkembangan pradewasa parasitoid $E$. argenteopilosus pada masing-masing instar larva S. litura

\begin{tabular}{|c|c|c|c|c|}
\hline Perlakuan & \multicolumn{2}{|c|}{$\begin{array}{l}\text { Lama perkembangan } \\
\quad \mathrm{X} \pm \mathrm{sd} \text { (hari) }\end{array}$} & \multicolumn{2}{|c|}{$\begin{array}{l}\text { Laju perkembangan } \\
\quad \mathrm{X} \pm \mathrm{sd}^{\left(\text {hari }^{-1}\right)}\end{array}$} \\
\hline \multicolumn{5}{|c|}{ Telur - Prapupa } \\
\hline 1. Instar 1 & \multirow{2}{*}{\multicolumn{2}{|c|}{$\begin{array}{l}19,50 \pm 2,8 \mathrm{a} \\
15,60 \pm 2,1 \mathrm{~b}\end{array}$}} & \multicolumn{2}{|c|}{$0,051 \pm 0,009$ a } \\
\hline 2. Instar 2 & & & \multicolumn{2}{|c|}{$0,064 \pm 0,011 \mathrm{~b}$} \\
\hline 3. Instar 3 & & & $79 \pm 0,96 \quad c$ \\
\hline 4. Instar 4 & \multicolumn{2}{|c|}{0} & \multirow{2}{*}{\multicolumn{2}{|c|}{$\begin{array}{c}0 \\
0\end{array}$}} \\
\hline \multicolumn{4}{|c|}{ Pupa - Imago } & \\
\hline 1. Instar 1 & \multicolumn{2}{|c|}{$10 \pm 3,16$ a } & \multicolumn{2}{|c|}{$0,10 \pm 0,1 \mathrm{a}$} \\
\hline 2. Instar 2 & \multirow{2}{*}{\multicolumn{2}{|c|}{$8,5 \pm 3,6 b$}} & \multicolumn{2}{|c|}{$0,12 \pm 0,1 \mathrm{~b}$} \\
\hline 3. Instar 3 & & & \multicolumn{2}{|r|}{0} \\
\hline 4. Instar 4 & \multicolumn{2}{|c|}{0} & & 0 \\
\hline \multicolumn{5}{|c|}{ Telur - Imago } \\
\hline 1. Instar 1 & \multicolumn{2}{|c|}{$29,50 \pm 3,81$ a } & \multicolumn{2}{|c|}{$0,03 \pm 0,007$ a } \\
\hline 2. Instar 2 & \multicolumn{2}{|c|}{$24,1 \pm 3,04 \quad b$} & \multicolumn{2}{|c|}{$0,04 \pm 0,028 \quad b$} \\
\hline 3. Instar 3 & \multicolumn{2}{|c|}{0} & \multicolumn{2}{|r|}{0} \\
\hline 4. Instar 4 & \multicolumn{2}{|c|}{0} & \multicolumn{2}{|r|}{0} \\
\hline \multicolumn{5}{|c|}{$\begin{array}{l}\text { Angka yang diikuti oleh huruf yang sama pada kolom yang sama pada masing-masing perlakuan } \\
\text { tidak berbeda nyata dengan uji lanjut Tukey pada taraf nyata } 5 \%\end{array}$} \\
\hline \multicolumn{5}{|c|}{ Keterangan: $0=$ Tidak muncul imago parasitoid } \\
\hline \multicolumn{5}{|c|}{$\begin{array}{l}\text { Tabel 2. Jumlah pupa dan imago parasitoid E. argenteopilosus yang muncul pada } \\
\text { masing-masing instar larva } S \text {. litura }\end{array}$} \\
\hline \multirow[t]{2}{*}{ Perlakuan } & \multirow{2}{*}{$\begin{array}{l}\text { Jumlah larva inang } \\
\text { terparasit (Ekor) }\end{array}$} & \multicolumn{2}{|c|}{ Jumlah } & \multirow{2}{*}{$\begin{array}{c}\text { Imago yang } \\
\text { muncul (Ekor) }\end{array}$} \\
\hline & & prapupa & Pupa & \\
\hline 1. Instar 1 & 300 & 11 & $3(1 \%)$ & $1(0,33 \%)$ \\
\hline 2. Instar 2 & 300 & 17 & $10(3,3 \%)$ & $2(0,66 \%)$ \\
\hline 3. Instar 3 & 300 & 4 & $1(0,33 \%)$ & 0 \\
\hline 4. Instar 4 & 300 & 0 & 0 & 0 \\
\hline
\end{tabular}


Tidak satupun pupa terbentuk dari larva inang instar 4 (Tabel 2).

\section{Jumlah Imago Parasitoid yang Muncul}

Hasil pengamatan jumlah imago parasitoid yang muncul dari masingmasing instar larva $S$. litura sangat sedikit (Tabel 2). Imago yang muncul adalah dari larva inang instar 1 sebanyak 1 ekor dan dari larva inang instar 2 sebanyak 2 ekor. Imago yang muncul adalah imago jantan.

Laju sintasan pradewasa E. argenteopilosus pada larva inang S. litura setiap harinya semakin menurun selama waktu pemeliharaan. Jumlah inang yang telah diparasit oleh $E$. argenteopilosus, selama pemeliharaan cenderung menurun jumlahnya. Semakin tua instar larva inang yang terparasit semakin cepat terjadi kematian.

Lama perkembangan telur prapupa pada masing-masing instar larva inang bervariasi. Semakin tua instar larva, semakin pendek waktu berkembang telur - prapupa. Ini diduga karena lama stadia pradewasa parasitoid mengikuti lama stadia inang. Aktivitas makan larva inang yang terparasit jadi berkurang, sehingga dapat menurunkan kebugaran larva inang. Perkembangan parasitoid yang ada dalam larva inang juga akan mengalami hal yang sama. Hal lain diduga kebutuhan nutrisi parasitoid jadi berkurang dan perkembangan parasitoid jadi lambat atau tidak berkembang sama sekali. Kualitas inang akan sesuai dengan kandungan nutrisi yang ada pada tubuh inang. Semakin besar larva inang maka nutrisi yang dikandungnya juga banyak sehingga mencukupi untuk perkembangan parasitoid sekaligus akan mempengaruhi laju perkembangan parasitoid itu sendiri. Godfray (1994) mengemukakan bahwa semakin besar

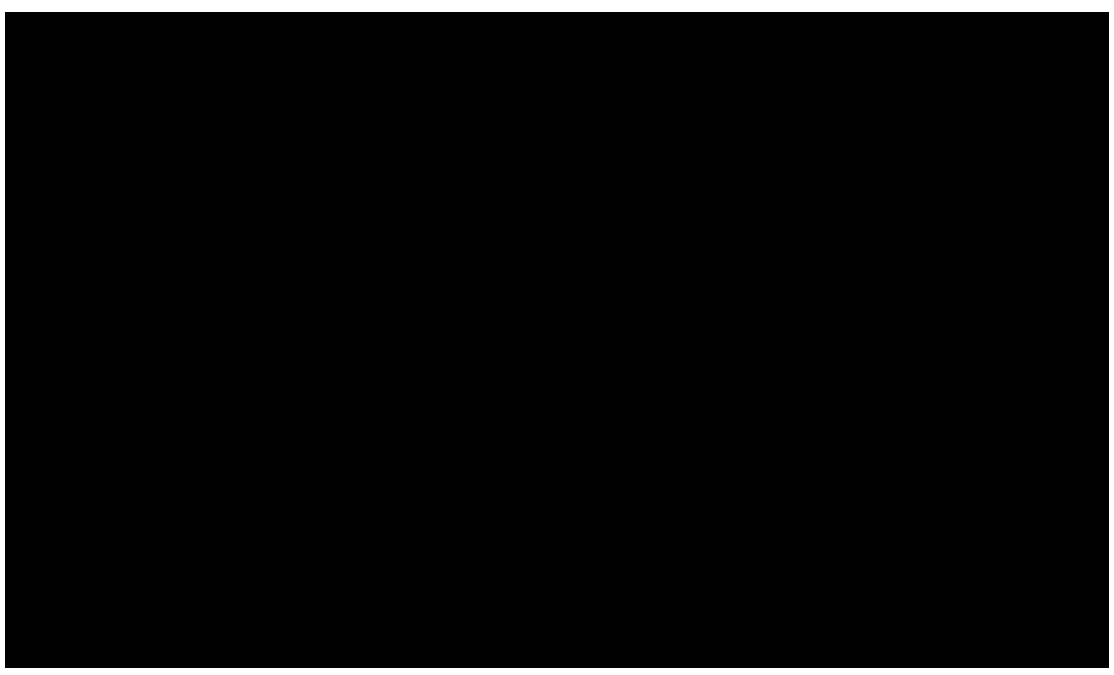

Gambar 1. Grafik laju sintasan pradewasa E. argenteopilosus dalam pemeliharaan pada 4 instar yang berbeda 
ukuran larva inang maka kandungan nutrisinya semakin baik untuk perkembangan parasitoid.

Lama dan laju perkembangan parasitoid menunjukkan bahwa semakin tinggi tingkatan instar larva inang maka dibutuhkan waktu yang lebih pendek untuk menyelesaikn siklus hidup. Laju perkembangan E. argenteopilosus pada larva inang S. litura instar tua, lebih tinggi dibanding instar yang lebih muda. Pradewasa parasitoid dalam pemeliharaan pada larva inang, laju perkembangannnya dipengaruhi oleh beberapa faktor, yaitu faktor kualitas dan kuantitas inang.

Keberhasilan pembentukan pupa dipengaruhi oleh keberhasilan telur dan larva parasitoid dalam mengatasi sistem pertahanan inang. Sedikitnya jumlah pupa yang terbentuk diduga karena larva $S$. litura yang terparasit mungkin memang berhasil bertahan hidup dan mencapai tahap pupa namun pupa yang terbentuk memiliki bentuk yang tidak bagus atau tidak normal. Beberapa hal diduga yang menyebabkan tidak terbentuknya pupa adalah bentuk prapupa yang tidak sempurna atau rumah pupa tidak terbentuk. Hasil penelitian Nelly (2005) pada C. pavonana yang terparasit oleh $E$. argenteopilosus menunjukkan bahwa pupa parasitoid bisa terbentuk tapi dalam perkembangan tidak menjadi imago karena terjadi gagal pupa, yaitu rumah pupa terbentuk akan tetapi larva tidak berkembang menjadi pupa.
Pengamatan yang dilakukan Sahari (1999) menjelaskan bahwa perkembangan pradewasa parasitoid pada larva inang $S$. litura instar 2 lebih baik dibanding instar 1. Hasil ini memperlihatkan bahwa larva parasitoid yang berhasil mengatasi perlawanan sistem pertahanan inang akan tumbuh dengan baik. Larva $S$. litura juga mempunyai sistem pertahanan inang berupa enkapsulasi telur parasitoid. Sedikitnya jumlah pupa yang terbentuk dari larva instar 3 diduga karena terjadinya enkapsulasi. Sahari (1999) melaporkan bahwa semakin tua larva $S$. litura, menunjukkan semakin cepat terjadinya enkapsulasi. Hal ini disebabkan pada larva inang yang lebih tua akan memiliki ukuran tubuh yang lebih besar dibandingkan larva yang lebih muda. Inang yang besar akan memiliki jumlah hemosit yang lebih banyak, sehingga kemampuan inang untuk mengenkapsulasi menjadi lebih tinggi (Salt 1963 dalam Blumberg 1997). Godfray (1994) mengungkapkan bahwa larva inang yang lebih besar akan memiliki pertahanan yang lebih kuat baik secara fisik maupun fisiologinya.

Jumlah imago yang muncul sangat sedikit, ini karena tidak semua prapupa terbentuk menjadi pupa dan tidak semua pupa berhasil menjadi imago. Faktor lain mungkin karena inang tidak terparasit, artinya parasitoid tidak meletakkan telur walaupun parasitoid menusukkan ovipositor. 


\section{KESIMPULAN}

Lama perkembangan telur sampai prapupa parasitoid E. argenteopilosus menunjukkan perbedaan dari masingmasing instar larva inang. Semakin tua instar larva inang semakin pendek waktu untuk terbentuk prapupa.

Laju perkembangan parasitoid $E$. argenteopilosus lebih cepat terjadi pada larva inang instar 3 karena semakin tinggi tingkatan instar larva inang waktu yang tersedia bagi parasitoid lebih pendek untuk menyelesaikan siklus hidup.

Larva inang yang terparasit tetap bertahan hidup, meskipun pertumbuhannya lambat dan tidak semua larva inang menjadi pupa dan imago. Jumlah pupa yang terbentuk adalah 14 pupa $(4,67 \%)$, dan parasitoid yang berhasil menjadi imago adalah 3 ekor (1\%), imago yang muncul hanya imago jantan.

\section{DAFTAR PUSTAKA}

Anindhita K. 2000. Oviposisi, Enkapsulasi dan Keberhasilan Hidup Parasitoid Eriborus argenteopilosus Cameron (Hymenoptera: Ichneumonidae), Spodoptera litura Fabricius dan Helicoverpa armigera Lepidoptera: Noctuidae) [skripsi]. Bogor: Jurusan Hama dan Penyakit Tumbuhan Fakultas Pertanian. IPB.

Arifin M. 1992. Kerusakan daun kedelai Orba pada Berbagai Umur Tanaman dan Populasi Ulat Grayak (Spodoptera litura).
Bogor: Seminar Hasil Penelitian Tanaman Pangan. Balai Penelitian Tanaman. 30 hal

Balai Informasi Pertanian Sumatera Barat. 1990. Beberapa Organisme Pengganggu Tanaman Pangan. Sumatera Barat: Departemen Pertanian.

Direktorat Bina Perlindungan Tanaman Pangan. 1994. Pengenalan Organisme Pengganggu Tumbuhan Secara Terpadu pada Tanaman Kubis. Jakarta: Direktorat Bina Perlindungan Tanaman.

Gani, Yunita. 1990. Pengaruh Beberapa Konsentrasi Insektisida Biologi Thuricidae WP Terhadap Mortalitas Larva Spodoptera litura $\mathrm{F}$ pada Tanaman Kedelei (Glycine max L) Merril) [thesis]. Padang: Fakultas Pertanian Universitas Andalas.

Godfray, H. C. J. 1994. Parasitoids, Behavioral and Evolutionary Ecology. New Jersey: Princeton University Press. Princeton.

Hadi, S. 1985. Biologi dan Perilaku Inareolata sp (Hymenoptera: Ichneumonidae) Parasitoid Larva Pada Hama Kubis Crocidolomia binotalis Zeller (Lepidoptera: Noctuidae) [thesis]. Bogor: Program Pasca Sarjana. IPB.

Heriyano, N. 2000. Perubahan Strategi Reproduksi Eriborus argenteopilosus Cameron (Hymenoptera : Ichneumonidae) Sebagai Tanggap Terhadap Ketiadaan Inang Crocidolomia binotalis Zell (Lepidoptera:Pyralidae) [skripsi]. Bogor: Institut Pertanian Bogor.

Kalshoven LGE. 1981. Pest of Crops in Indonesia. Laan PA van der, 
penerjemah. Jakarta: PT. Ichtiar Baru Van Hoeve. Terjemahan dari: De Plagen van de Cultuurgewassen in Indonesie.

Kardinan A. 1999. Pestisida Nabati dan Ramuan Aplikasi. Jakarta: Penebar Swadaya.

Kurniawati D. 1998. Kesesuaian Instar Larva Spodoptera litura Fabricius (Lepidoptera:Noctuidae) Sebagai Inang Parasitoid Larva Snellenius (=Microplitis) manilae Ashmead (Hymenoptera: Braconidae). Bogor: Laporan Makalah Khusus. Jurusan Hama dan Penyakit Tumbuhan Fakultas Pertanian Insitut Pertanian Bogor.

Nelly N. 2005. Dinamika Interaksi Parasitoid Eriborus argenteopilosus Cameron (Hymenoptera: Ichneumonidae) dan Inang Crocidolomia pavonana Zeller (Lepidoptera:Pyralidae) pada Kondisi Fisiologis dan Suhu Berbeda [disertasi]. Padang: Program Pascasarjana. Universitas Andalas.

Othman N. 1982. Biology of Crocidolomia binotalis Zell (Lepidop- tera: Pyralidae) and its Parasites From Cipanas Area, West Java Bogor: a report of training course research) SEAMEO Regional Centre For Tropical Biology. 62 hal.

Pathak M. 1977. Insect Pest of Rice. International Rice Research Philliphines: Institute Los Banos.

Pusat Penelitian dan Pengembangan Tanaman Pangan. 1990. Petunjuk Bergambar Untuk Identifikasi Hama dan Penyakit Kedelai Di Indonesia. Bogor: Balai Penelitian Tanaman Pangan.

Sahari B. 1999. Studi Parasitoid Eriborus argenteopilosus Cameron (Hymenoptera: Ichneumonidae) dan Implikasinya pada Inang Crocidolomia pavonana Zeller (Lepidoptera:Pyralidae) dan Spodoptera litura Fabricius (Lepidoptera:Noctuidae) [skirpsi]. Jurusan Hama dan Penyakit Tumbuhan. IPB. Bogor. 57 hal.

Soedarmo S. 1992. Pengendalian Serangga Hama Sayuran dan Palawija. Jakarta: Kanisius. 